\title{
Synthesis, Molecular Docking and Tyrosinase Inhibitory Activity of the Decorated Methoxy Sulfonamide Chalcones: in vitro Inhibitory Effects and the Possible Binding Mode
}

(Sintesis, Penyambungan Molekul dan Aktiviti Perencatan Tirosinase dari Metoksi Sulfonamida Kalkon: Kesan Perencatan in vitro dan Mod Pengikatan Mungkin)

\author{
ThaWANRat KobKeatthawin, Suchada Chantrapromma*, Thitipone SuWunwong, Lydia Rhyman,
} YeE Siew Choong \& Ponnadurai Ramasami

\begin{abstract}
In this study, a series of sulfonamide chalcones derivatives was synthesized and its chemical structures were confirmed by spectral characteristics. The synthesized compounds were evaluated for their tyrosinase inhibitory activities along with molecular docking study. The tyrosinase inhibitory results indicated that compounds $5 b$, 5c, $5 f, 5 g$ and $5 \mathrm{~h}$ displayed the significant tyrosinase inhibitory activity and comparable to the standard drug (kojic acid). Compound $5 c$ exhibits the most potent tyrosinase inhibition among the synthesized compounds with $\mathrm{IC}_{50}=0.43 \pm 0.07 \mathrm{mM}$, $L-D O P A$ as the substrate, and better than that of the standard kojic acid $\left(I C_{50}=0.60 \pm 0.20 \mathrm{mM}\right)$. Molecular docking studies showed that the binding mode of some compounds is in the tyrosinase binding pocket surrounding the copper in the active site. The correlation between the docking results with $I_{50}$ values showed that the binding mode prediction of the test compounds would also be convincing. This comprehensive study allows for a possible mechanism for the antityrosinase activity of the sulfonamide chalcones. These sulfonamide chalcones bind to copper atoms of tyrosinase which responsible for the catalytic activity of tyrosinase. These compounds may be used as a lead for rational drug designing for the multi-functional tyrosinase inhibitor.
\end{abstract}

Keywords: Binding mode; molecular docking; sulfonamide chalcones; tyrosinase inhibitor

\section{ABSTRAK}

Dalam kajian ini, satu siri terbitan sulfonamida kalkon disintesis dan struktur kimianya disahkan oleh pencirian spektrum. Sebatian yang disintesis dinilai untuk aktiviti penghambatan tirosinasenya bersama dengan kajian mengedok molekul. Hasil perencatan tirosinase menunjukkan bahawa sebatian 5b, 5c, 5 f, $5 \mathrm{~g}$ dan 5 h menunjukkan aktiviti penghambatan tirosinase yang signifikan dan setanding dengan ubat piawai (asid kojik). Sebatian 5c menunjukkan perencatan tirosinase yang paling kuat antara sebatian yang disintesis dengan $I_{50}=0.43 \pm 0.07 \mathrm{mM}$, L-DOPA sebagai substrat dan lebih baik daripada asid kojik piawai $\left(I_{50}=0.60 \pm 0.20 \mathrm{mM}\right)$. Kajian mengedok molekul menunjukkan bahawa kaedah pengikatan sebilangan sebatian terdapat di dalam poket pengikat tirosinase yang mengelilingi tembaga di tapak aktif. Hubungan antara hasil dok dengan nilai $I C_{50}$ menunjukkan bahawa ramalan mod pengikat sebatian ujian juga akan meyakinkan. Kajian komprehensif ini memungkinkan adanya mekanisme untuk aktiviti anti-tirosinase sulfonamida kalkon. Kalkon sulfonamida ini mengikat atom tembaga tirosinase yang bertanggungjawab untuk aktiviti pemangkin tirosinase. Sebatian ini boleh digunakan sebagai petunjuk untuk mereka bentuk ubat yang rasional untuk perencat tirosinase pelbagai fungsi.

Kata kunci: Dok molekul; mod pengikat; perencat tirosinase; sulfonamida kalkon 


\section{INTRODUCTION}

Tyrosinase (E.C.1.14.18.1) is a copper-containing monooxygenase that is widely distributed in microorganisms, animals, and plants (Nithitanakool et al. 2009). The tyrosinase enzyme catalyzed the rate-limiting step for the biosynthesis of melanin. The synthesis of melanin starts from the conversion of L-tyrosine to 3,4-dihydroxyphenylalanine (L-DOPA) and the latter is then oxidized to dopaquinone which is further transformed through several reactions to yield brown to black melanin that is responsible for skin color of mammals (Chang 2009; Panzella \& Napolitano 2019; Parvez et al. 2007). Melanin helps to protect skin from the damaging UV radiation of the sun. However, the accumulation of excessive melanin causes disorders such as freckles (Yamada et al. 2011) and defect (Seo et al. 2003). Therefore, the control of tyrosinase activity is of fundamental importance. Chalcones is a class of natural substance that has shown antityrosinase activity in-vitro, with the competition mechanism due to a similar structure of substrate (Radhakrishnan et al. 2015a; Seo et al. 2010). In addition, it has favourable interaction with the copper atom or hydrophobic protein pocket surrounding the binuclear copper active site of tyrosinase (Akhtar et al. 2015; Cai et al. 2019). Chalcone derivatives were reported to have potent tyrosinase inhibitor (Liu et al. 2013; Niu et al. 2016; Ranjbar et al. 2018). Similarly, there are reports involving compounds 1-4 in Figure 1 showing that hydroxy and methoxy substitutions have good effect to the tyrosinase inhibitory (Khatib et al. 2005; Liozzo et al. 2012; Nerya et al. 2004; Radhakrishnan et al. 2015b). The presence of an electron donating group on the atoms adjacent to the $\pi$ system, which activate the aromatic ring by increasing the electron density on the ring through a resonance donating effect, is considered important as it is involved in binding to the $\mathrm{Cu}$ atoms of the tyrosinase active site (Radhakrishnan et al. 2015c). So, methoxy substitutions are a good candidate in this study. Beside chalcones, sulfur is also important, it is not only involved in living cell but also the key component of some proteins which are essential for health. Some of sulfur-containing compounds have been found to show antioxidant (Ali \& Abdel-Rahman 2014; Battin \& Brumaghim 2009; Kim et al. 2020), anticancer (Yi \& Su 2013) and tyrosinase inhibitory (Carcelli et al. 2020; Lee et al. 2016; Liu et al. 2011). Especially, sulfonamides are antibiotics commonly used to treat infectious disease. The structure of sulfonamides containing an $-\mathrm{SO}_{2} \mathrm{NH}-$ group which can be found in many pharmacologically active compounds including antityrosinase compounds (Rescigno et al. 2011).

Although several chalcone and sulfonamide derivatives show good tyrosinase inhibitory but there are only few compounds which can be used in clinical trials due to their toxicity. Therefore, cosmetic and medical markets are searching for the effective, safer and biosynthesized whitening agent that can reduce melanin without cytotoxicity. As reported earlier, two combined pharmacophores have been shown to exhibit synergistic effect in biological activity (Ashraf et al. 2018; Javle $\&$ Curtin 2011) such as antimalarial (Domínguez et al. 2005), Alzheimer's (Kang et al. 2013), anti $\alpha$-glucosidase (Bharatham et al. 2008), anticancer (Bonakdar et al. 2017) and antityrosinase (Seo et al. 2010). In addition, it is also found in the cosmetic compositions (Park et al. 2010). In view of these, even though there are studies on the bioactivity of sulfonamide chalcones, only few tyrosinase compounds of sulfonamide chalcones are reported (Seo et al. 2010). These led us to design and synthesize sulfonamide chalcone derivatives (Figure 2), and characterized them by ${ }^{1} \mathrm{H}-\mathrm{NMR}$, FT-IR, UV-Vis spectroscopy and elemental analysis. The influence of the different positions of methoxy substituents was determined on antityrosinase activity. Antityrosinase assays were performed with L-DOPA as the substrate and using kojic acid, a well-known strong tyrosinase inhibitor as the positive control. In addition to the experimental study of the antityrosinase activity, the possible binding mode between tyrosinase enzyme and sulfonamide chalcones was also investigated using molecular docking simulation.

\section{Materials AND Methods}

\section{CHEMICALS}

All reagents and solvents for synthesis and analysis are commercially available and used as received. Methanol (MeOH), dimethylsulfoxide (DMSO) and pyridine from Merck. Sodium hydroxide $(\mathrm{NaOH})$ from Lab-Scan Analytical Sciences, Labscan Asia. Co. whereas 4-aminoacetophenone, 4-chlorobenzene1 -sulfonyl chloride and all benzaldehydes were obtained from Fluka. Sodium hydrogen phosphate $\left(\mathrm{Na}_{2} \mathrm{HPO}_{4}\right)$, sodium dihydrogen phosphate $\left(\mathrm{NaH}_{2} \mathrm{PO}_{4}\right)$, 3,4-dihydroxyphenylalanine (L-DOPA) and tyrosinase enzyme from Sigma-Aldrich Chemical Co. 


\section{EQUIPMENTS}

Infrared spectrum was recorded using FT-IR System Spectrum BX spectrophotometer in the range of 4000-400 $\mathrm{cm}^{-1}$ in $\mathrm{KBr}$ pellets. The ${ }^{1} \mathrm{H}-\mathrm{NMR}$ spectra were obtained on $300 \mathrm{MHz}$ Bruker FT-NMR Ultra ShieldTM spectrometer in deuterated acetone $\left(\mathrm{CD}_{3}\right)_{2} \mathrm{CO}$ solution with TMS as the internal standard. The UV-Vis absorption spectra were acquired using a SPECORD S100 (Analytikjena) UV-Visible spectrophotometer. Melting point was measured using an Electrothermal melting point apparatus. $\mathrm{C}, \mathrm{H}$ and $\mathrm{N}$ analysis by $\mathrm{CHNS} / \mathrm{O}$ : Thermo Quest FlashEA 1112. The \% inhibition of tyrosinase was recorded using a microplate reader.

\section{SYNTHESIS OF $N$-(4-ACETYLPHENYL)-4- CHLOROBENZENE-SULFONAMIDE (3)}

The sulfonamide chalcones were synthesized according to the reported protocol (Gantla et al. 2009). Compound 3 (Scheme 1) namely $N$-(4-acetylphenyl)-4-chlorobenzenesulfonamide, was synthesized by condensation of 4-chlorobenzene sulfonylchloride $(0.01 \mathrm{~mol})(1)$ and 4-aminoacetophenone $(0.01 \mathrm{~mol})(2)$ in methanol (40 $\mathrm{mL})$ in the presence of pyridine $(5 \mathrm{~mL})$. The reaction mixture was refluxed for $3 \mathrm{~h}$ and monitored with TLC for the completion of reaction. The solution is poured into crushed ice and acidified with $\mathrm{HCl}$. The white solid of the product appeared immediately and was filtrated off with the yield being $85 \%$ and the melting point is $165-166{ }^{\circ} \mathrm{C}$.

\section{SYNTHESIS OF SULFONAMIDE CHALCONES (5A-5H)}

The solution of $1 \mathrm{mmol}$ of compound 3 in methanol (20 $\mathrm{mL})$, the solution of $1 \mathrm{mmol}$ of different benzaldehydes (4) in methanol $(20 \mathrm{~mL})$ and $25 \%$ aqueous $\mathrm{NaOH}(5 \mathrm{~mL})$ were mixed and stirred at room temperature for 5-8 h and monitored with TLC until the completion of reaction. The contents were poured onto crushed ice and the $\mathrm{pH}$ was adjusted to 7 by $\mathrm{HCl}$ (conc.). The compound was filtered and washed with water and ethanol. The resulting solid of the product was further purified by column chromatography to afford compounds 5a-5h (Scheme 1) as yellow solid, yield 50-78 \%.

\section{ANTITYROSINASE ASSAY}

The tyrosinase inhibition activity of sulfonamide chalcones (5a-5h) and standard sample (kojic acid) were studied by using mushroom tyrosinase as enzyme and L-DOPA as substrate. The test assay was performed according to reported protocol (Suwunwong et al. 2012). The tested compounds were dissolved in DMSO at 1.0 $\mathrm{mg} / \mathrm{mL}$ and then diluted to different concentrations using DMSO. Each substrate was dissolved in $0.1 \mathrm{M}$ phosphate buffer ( $\mathrm{pH}$ 6.8). The solution of substrates $0.85 \mathrm{mM}$ of L-DOPA in $0.1 \mathrm{M}$ phosphate buffer ( $\mathrm{pH}$ 6.8) was added in the reaction, the mushroom tyrosinase solution (245 units) was then added, and was left for $20 \mathrm{~min}$. The dopachrome formation was measured using microplate reader at $490 \mathrm{~nm}$. The percentage of tyrosinase inhibition activity was calculated using (1).

$$
\% \text { Tyrosinase inhibition }=\frac{[(A-B)-(C-D)]}{(A-B)} \times 100
$$

where $\mathrm{A}$ is absorbance of control; $\mathrm{B}$ is absorbance of blank control; $\mathrm{C}$ is absorbance of test sample; and D is absorbance of blank sample. The extent of inhibition by the addition of samples is expressed as the percentage necessary for $50 \%$ inhibition $\left(\mathrm{IC}_{50}\right)$. The $\mathrm{IC}_{50}$ values were further determined by obtaining \% inhibitions of the samples in various concentrations and were calculated by linear regression analysis from the mean inhibitory values. All tests were performed in triplicate.

\section{MOLECULAR DOCKING STUDY PROTEIN STRUCTURE}

The starting structure of Agaricus bisporus tyrosinase was obtained from PDB (PDB id: 2Y9X) with resolution of 2.78 (Ismaya et al. 2011). All heteroatoms and water molecules were removed except for copper atoms. Polar hydrogen atoms, Kollman-Amber united atom partial charges and solvation parameters were added by utilizing AutoDockTools (Morris et al. 1998).

\section{LIGAND STRUCTURE}

The initial structure of tropolone (OTR; control for docking study) was obtained from the ligand of tyrosinase (PDB id: 2Y9X) while the coordinates for sulfonamide chalcone series (5a-5h) were generated using Hyperchem 7.0 (Hypercube, Inc. Florida). All ligands were retained with polar hydrogen atoms. Gasteiger charges and torsional angles were added by utilizing AutoDockTools (Morris et al. 1998). 


\section{MOLECULAR DOCKING SIMULATION}

Grid maps of $60 \times 60 \times 60$ points with $0.375 \AA$ spacing generated by AutoGrid3 were centered at the ligand binding site in the tyrosinase crystal structure. The docking was performed employing Lamarckian genetic algorithm with pseudo-Solis and Wets local search with population size of 50 and energy evaluation of 2,500,000; root mean square tolerance of $1.0 \AA$ and 100 docking runs by AutoDock3.0 (Morris et al. 1998). The ligand conformation with lowest free energy of binding in the most populated cluster was selected for analysis.

\section{RESULTS AND DISCUSSION}

\section{SPECTROSCOPIC DATA}

$N$-(4-acetylphenyl)-4-chlorobenzenesulfonamide (3)

M.p. $165-166{ }^{\circ} \mathrm{C}$; IR (KBr) cm ${ }^{-1}: 3257$ (N-H stretching), $1669(\mathrm{C}=\mathrm{O}$ stretching $), 1601(\mathrm{C}=\mathrm{C}$ stretching $), 1162(\mathrm{~S}=\mathrm{O}$ stretching), 1103 ( $\mathrm{S}=\mathrm{O}$ stretching); ${ }^{1} \mathrm{H}-\mathrm{NMR}(300 \mathrm{MHz}$, DMSO-d $) \delta$ ppm: $10.75(s, \mathrm{NH}), 7.84(d, 2 \mathrm{H}, J=8.7 \mathrm{~Hz})$, $7.77(d, 2 \mathrm{H}, J=8.7 \mathrm{~Hz}), 7.20(d, 2 \mathrm{H} J=8.7 \mathrm{~Hz}), 7.05$ $(d, 2 \mathrm{H}, J=8.7 \mathrm{~Hz}), 3.80\left(s, \mathrm{H}_{\text {methoxy }}\right), 2.43\left(s, \mathrm{H}_{\text {methyl }}\right)$; $\mathrm{UV}-\mathrm{Vis}(\mathrm{EtOH}) \lambda_{\max }(\mathrm{nm}): 274$ and 333. Calculated for $\mathrm{C}_{14} \mathrm{H}_{12} \mathrm{ClNO}_{3} \mathrm{~S}\left(309.77 \mathrm{gmol}^{-1}\right): \mathrm{C}, 54.27 ; \mathrm{H}, 3.91 ; \mathrm{N}, 4.52$. Found: C, 54.15; H, 3.89; N, 4.48 .

(E)-4-chloro-N-(4-(3-2-methoxyphenyl)acryloyl)phenyl) benzenesulfonamide (5a)

M.p. $180-181{ }^{\circ} \mathrm{C}$; IR ( $\left.\mathrm{KBr}\right) \mathrm{cm}^{-1}$ : 2925 (N-H stretching), $1602(\mathrm{C}=\mathrm{O}$ stretching), $1339(\mathrm{C}=\mathrm{C}$ stretching $), 1162$ ( $\mathrm{S}=\mathrm{O}$ stretching), 1093 ( $\mathrm{S}=\mathrm{O}$ stretching); ${ }^{1} \mathrm{H}-\mathrm{NMR}(300$ MHz, Acetone- $\left.\mathrm{d}_{6}\right) \delta \mathrm{ppm}: 8.05(d, 1 \mathrm{H}, J=15.6 \mathrm{~Hz}$, trans), $7.91(d, 2 \mathrm{H}, J=8.4 \mathrm{~Hz}), 7.83(d, 2 \mathrm{H}, J=9.0 \mathrm{~Hz}), 7.77(d$, $1 \mathrm{H}, J=15.6 \mathrm{~Hz}$, trans), $7.40(d, 2 \mathrm{H}, J=9.0 \mathrm{~Hz}), 7.38(d$, $1 \mathrm{H} J=8.7 \mathrm{~Hz}), 7.20(d d, 1 \mathrm{H}, J=9.0,3.0 \mathrm{~Hz}), 7.11(d d, 1 \mathrm{H}$, $J=9.0,3.0 \mathrm{~Hz}), 7.05(d, 2 \mathrm{H}, J=9.0 \mathrm{~Hz}), 7.01(d d, 1 \mathrm{H}, J$ $=9.0,3.0 \mathrm{~Hz}), 3.98\left(\mathrm{~s}, \mathrm{H}_{\text {methoxy }}\right)$. UV-Vis (Acetronitrile) $\lambda_{\max }(\mathrm{nm}): 271$ and 347. Calculated for $\mathrm{C}_{22} \mathrm{H}_{18} \mathrm{ClNO}_{4} \mathrm{~S}$ (427.90 gmol$\left.^{-1}\right): \mathrm{C}, 61.74 ; \mathrm{H}, 4.24 ; \mathrm{N}, 3.27$. Found: C, 61.69; H, 4.20; N, 3.22.

(E)-4-chloro-N-(4-(3-3-methoxyphenyl)acryloyl)phenyl) benzenesulfonamide (5b)

M.p. $184-185^{\circ} \mathrm{C}$; IR ( $\left.\mathrm{KBr}\right) \mathrm{cm}^{-1}$ : 2924 (N-H stretching), $1541(\mathrm{C}=\mathrm{O}$ stretching $), 1254(\mathrm{C}=\mathrm{C}$ stretching $), 1161$ ( $\mathrm{S}=\mathrm{O}$ stretching), 1092 ( $\mathrm{S}=\mathrm{O}$ stretching); ${ }^{1} \mathrm{H}-\mathrm{NMR}$ (300 MHz, Acetone-d $\left.{ }_{6}\right) \delta$ ppm: $8.09(d, 2 \mathrm{H}, J=9.0 \mathrm{~Hz}), 7.90$ $(d, 2 \mathrm{H}, J=8.7 \mathrm{~Hz}), 7.84(d, 1 \mathrm{H}, J=15.6 \mathrm{~Hz}$, trans $), 7.72$ $(d, 1 \mathrm{H}, J=15.6 \mathrm{~Hz}$, trans), $7.62(d, 2 \mathrm{H}, J=8.7 \mathrm{~Hz}), 7.40$ $(m, 6 \mathrm{H}), 3.34\left(s, \mathrm{H}_{\text {methoxy }}\right)$. UV-Vis (Acetronitrile) $\lambda_{\max }$ (nm): 240 and 278. Calculated for $\mathrm{C}_{22} \mathrm{H}_{18} \mathrm{ClNO}_{4} \mathrm{~S}(427.90$ gmol $^{-1}$ ): C, 61.74; H, 4.24; N, 3.27. Found: C, 61.70; H, $4.22 ; \mathrm{N}, 3.19$.

(E)-4-chloro-N-(4-(3-4-methoxyphenyl)acryloyl)phenyl) benzenesulfonamide (5c)

M.p. 154- $155^{\circ} \mathrm{C}$; IR (KBr) cm ${ }^{-1}: 2924$ (N-H stretching), $1650(\mathrm{C}=\mathrm{O}$ stretching $), 1558(\mathrm{C}=\mathrm{C}$ stretching $), 1162$ $(\mathrm{S}=\mathrm{O}$ stretching), $1092(\mathrm{~S}=\mathrm{O}$ stretching $) ; 8.09(d, 2 \mathrm{H}$, $J=8.7 \mathrm{~Hz}), 7.92(d, 2 \mathrm{H}, J=8.7 \mathrm{~Hz}), 7.78(d, 2 \mathrm{H}, J=$ $8.7 \mathrm{~Hz}), 7.75(d, 1 \mathrm{H}, J=15.6 \mathrm{~Hz}$, trans $), 7.68(d, 1 \mathrm{H}, J$ $=15.6 \mathrm{~Hz}$, trans $), 7.63(d, 2 \mathrm{H}, J=8.7 \mathrm{~Hz}), 7.40(d, 2 \mathrm{H}$, $J=8.7 \mathrm{~Hz}), 7.03(d, 2 \mathrm{H}, J=8.7 \mathrm{~Hz}), 3.87$ (s, $\left.\mathrm{H}_{\text {methoxy }}\right)$. UV-Vis $(\mathrm{MeOH}) \lambda_{\text {max }}(\mathrm{nm}): 213,300$ and 364. Calculated for $\mathrm{C}_{22} \mathrm{H}_{18} \mathrm{ClNO}_{4} \mathrm{~S}\left(427.90 \mathrm{gmol}^{-1}\right)$ : C, 61.74; H, 4.24; N, 3.27. Found: C, 61.65; H, 4.17; N, 3.25.

(E)-4-chloro-N-(4-(3-(2,3-dimethoxyphenyl)acryloyl) phenyl)benzenesulfonamide (5d)

M.p. $145-146{ }^{\circ} \mathrm{C}$; IR (KBr) cm ${ }^{-1}: 3025$ (N-H stretching), $1603(\mathrm{C}=\mathrm{O}$ stretching $), 1379(\mathrm{C}=\mathrm{C}$ stretching $), 1168$ ( $\mathrm{S}=\mathrm{O}$ stretching), 1099 ( $\mathrm{S}=\mathrm{O}$ stretching); ${ }^{1} \mathrm{H}-\mathrm{NMR}(300$ $\left.\mathrm{MHz}, \mathrm{CDCl}_{3}\right) \delta$ ppm: $8.07(d, 1 \mathrm{H}, J=15.6 \mathrm{~Hz}$, trans), $8.05(d, 2 \mathrm{H}, J=9.0 \mathrm{~Hz}), 7.92(d, 2 \mathrm{H}, J=8.4 \mathrm{~Hz}), 7.79$ $(d, 1 \mathrm{H}, J=15.6 \mathrm{~Hz}$, trans), $7.64(d d, 1 \mathrm{H}, J=9.0 \mathrm{~Hz}, 3.0$ $\mathrm{Hz}), 7.62(d d, 1 \mathrm{H}, J=9.0 \mathrm{~Hz}, 3.0 \mathrm{~Hz}), 7.50(t, 3 \mathrm{H}), 7.42$ $(d, 2 \mathrm{H}, J=9.0 \mathrm{~Hz}), 7.34(d, 2 \mathrm{H}, J=9.0 \mathrm{~Hz}), 3.89,3.86$ $\left(s, \mathrm{H}_{\text {methoxy }}\right)$. UV-Vis $(\mathrm{MeOH}) \lambda_{\max }(\mathrm{nm}): 226$ and 284. Calculated for $\mathrm{C}_{23} \mathrm{H}_{20} \mathrm{ClNO}_{5} \mathrm{~S}\left(457.93 \mathrm{gmol}^{-1}\right)$ : C, 60.32; H, 4.41; N, 3.05. Found: C, 60.27; H, 4.35; N, 3.00.

(E)-4-chloro-N-(4-(3-(3,4-dimethoxyphenyl)acryloyl) phenyl)benzenesulfonamide (5e)

M.p. $261-262{ }^{\circ} \mathrm{C}$; IR (KBr) cm $\mathrm{cm}^{-1}: 2923$ (N-H stretching), $1650(\mathrm{C}=\mathrm{O}$ stretching $), 1508(\mathrm{C}=\mathrm{C}$ stretching $), 1266$ ( $\mathrm{S}=\mathrm{O}$ stretching), $1022(\mathrm{~S}=\mathrm{O}$ stretching $) ;{ }^{1} \mathrm{H}-\mathrm{NMR}(300$ $\left.\mathrm{MHz}, \mathrm{CDCl}_{3}\right) \delta \mathrm{ppm}: 7.89(d, 2 \mathrm{H}, \mathrm{J}=9.0 \mathrm{~Hz}), 7.82(d, 2 \mathrm{H}$, $\mathrm{J}=9.0 \mathrm{~Hz}), 7.70(d, 1 \mathrm{H}, J=15.6 \mathrm{~Hz}$, trans $), 7.60(d, 2 \mathrm{H}, J$ $=9.0 \mathrm{~Hz}), 7.55(d d, 1 \mathrm{H} J=8.4 \mathrm{~Hz}, 3.0 \mathrm{~Hz}), 7.40(d, 2 \mathrm{H}, J$ $=9.0 \mathrm{~Hz}) 7.29(d d, 1 \mathrm{H} J=8.4 \mathrm{~Hz}, 3.0 \mathrm{~Hz}), 7.18(d, 2 \mathrm{H}, J$ $=9.0 \mathrm{~Hz}), 7.02(d, 2 \mathrm{H}, J=9.0 \mathrm{~Hz}), 3.83,3.40\left(s, \mathrm{H}_{\text {methoxy }}\right)$. UV-Vis $(\mathrm{MeOH}) \lambda_{\max }(\mathrm{nm}): 230$ and 287. Calculated for $\mathrm{C}_{23} \mathrm{H}_{20} \mathrm{ClNO}_{5} \mathrm{~S}\left(457.93 \mathrm{gmol}^{-1}\right): \mathrm{C}, 60.32 ; \mathrm{H}, 4.41 ; \mathrm{N}, 3.05$. Found: C, 60.29; H, 4.31; N, 3.03. 
(E)-4-chloro-N-(4-(3-(2,4,5-dimethoxyphenyl)acryloyl) phenyl)benzenesulfonamide (5f)

M.p. $224-225^{\circ} \mathrm{C}$; IR (KBr) cm ${ }^{-1}: 2923$ (N-H stretching), $1657(\mathrm{C}=\mathrm{O}$ stretching $), 1540(\mathrm{C}=\mathrm{C}$ stretching $), 1209(\mathrm{~S}=\mathrm{O}$ stretching), 1085 ( $\mathrm{S}=\mathrm{O}$ stretching); ${ }^{1} \mathrm{H}-\mathrm{NMR}(300 \mathrm{MHz}$, $\left.\mathrm{CDCl}_{3}\right) \delta \mathrm{ppm}: 7.90(d, 1 \mathrm{H}, J=15.6 \mathrm{~Hz}$, trans $), 7.77(d, 2 \mathrm{H}$, $J=9.0 \mathrm{~Hz}), 7.71(d, 2 \mathrm{H}, J=8.4 \mathrm{~Hz}), 7.66(d, 1 \mathrm{H}, J=15.6$ $\mathrm{Hz}$, trans), $7.45(s, 1 \mathrm{H}), 7.44(d, 2 \mathrm{H}, J=9.0 \mathrm{~Hz}), 6.80(d$, $2 \mathrm{H}, \mathrm{J}=9.0 \mathrm{~Hz}), 6.72(s, 1 \mathrm{H}), 3.86,3.84,3.80\left(s, \mathrm{H}_{\text {methoxy }}\right)$. UV-Vis $(\mathrm{MeOH}) \lambda_{\max }(\mathrm{nm}): 287,324$ and 403 . Calculated for $\mathrm{C}_{24} \mathrm{H}_{22} \mathrm{ClNO}_{6} \mathrm{~S}\left(487.95 \mathrm{gmol}^{-1}\right): \mathrm{C}, 59.07 ; \mathrm{H}, 4.55 ; \mathrm{N}$, 2.87. Found: C, 59.01; H, 4.49; N, 2.82.

(E)-4-chloro- $N$-(4-(3-(2,4,6-dimethoxyphenyl)acryloyl) phenyl)benzenesulfonamide (5g)

M.p. $217-218{ }^{\circ} \mathrm{C}$; IR (KBr) cm${ }^{-1}: 2938$ (N-H stretching), $1600(\mathrm{C}=\mathrm{O}$ stretching $), 1457(\mathrm{C}=\mathrm{C}$ stretching $), 1158(\mathrm{~S}=\mathrm{O}$ stretching), 1121 ( $\mathrm{S}=\mathrm{O}$ stretching); ${ }^{1} \mathrm{H}-\mathrm{NMR}(300 \mathrm{MHz}$, $\left.\mathrm{CDCl}_{3}\right) \delta$ ppm: $8.13(d, 1 \mathrm{H}, J=15.6 \mathrm{~Hz}$, trans $), 7.93(d$, $1 \mathrm{H}, J=15.6 \mathrm{~Hz}$, trans $), 7.82(d, 2 \mathrm{H}, J=8.4 \mathrm{~Hz}), 7.73(d$, $2 \mathrm{H}, J=8.4 \mathrm{~Hz}), 6.99(d, 2 \mathrm{H}, J=8.4 \mathrm{~Hz}), 6.86(d, 2 \mathrm{H}$, $J=8.4 \mathrm{~Hz}) 6.30(s, 2 \mathrm{H}), 3.91,3.87,3.77\left(s, \mathrm{H}_{\text {methoxy }}\right)$. UV-Vis $(\mathrm{MeOH}) \lambda_{\max }(\mathrm{nm}): 227$ and 284. Calculated for $\mathrm{C}_{24} \mathrm{H}_{22} \mathrm{ClNO}_{6} \mathrm{~S}\left(487.95 \mathrm{gmol}^{-1}\right): \mathrm{C}, 59.07 ; \mathrm{H}, 4.55 ; \mathrm{N}, 2.87$. Found: C, 58.87; H, 4.43; N, 2.80 .

(E)-4-chloro-N-(4-(3-(3,4,5-dimethoxyphenyl(acryloyl) phenyl)benzenesulfonamide ( $5 \mathrm{~h})$ M.p. $144-145^{\circ} \mathrm{C}$; IR (KBr) cm ${ }^{-1}: 2938$ (N-H stretching), $1669(\mathrm{C}=\mathrm{O}$ stretching $), 1602(\mathrm{C}=\mathrm{C}$ stretching $), 1162(\mathrm{~S}=\mathrm{O}$ stretching), 1093 ( $\mathrm{S}=\mathrm{O}$ stretching); ${ }^{1} \mathrm{H}-\mathrm{NMR}(300 \mathrm{MHz}$, $\left.\mathrm{CDCl}_{3}\right) \delta \mathrm{ppm}: 8.08(d, 2 \mathrm{H}, J=8.7 \mathrm{~Hz}), 7.87(d, 2 \mathrm{H}, J=$ $8.4 \mathrm{~Hz}), 7.82(d, 1 \mathrm{H}, J=15.6 \mathrm{~Hz}$, trans $), 7.68(d, 2 \mathrm{H}, J=$ $8.4 \mathrm{~Hz}), 7.63(d, 1 \mathrm{H}, J=15.6 \mathrm{~Hz}$, trans), $7.27(d, 2 \mathrm{H}, J$ $=8.4 \mathrm{~Hz}), 7.20(\mathrm{~s}, 2 \mathrm{H}), 3.85,3.76,3.71\left(\mathrm{~s}, \mathrm{H}_{\text {methoxy }}\right)$. UVVis $(\mathrm{MeOH}) \lambda_{\text {max }}$ (nm): 224, 281 and 351. Calculated for $\mathrm{C}_{24} \mathrm{H}_{22} \mathrm{ClNO}_{6} \mathrm{~S}\left(487.95 \mathrm{gmol}^{-1}\right): \mathrm{C}, 59.07 ; \mathrm{H}, 4.55 ; \mathrm{N}, 2.87$. Found: C, 59.00; H, 4.51; N, 2.84 .

\section{SYNTHESIS AND SPECTROSCOPIC ANALYSIS}

All the synthesized compounds were characterized by ${ }^{1} \mathrm{H}-\mathrm{NMR}, \mathrm{FT}-\mathrm{IR}, \mathrm{UV}-\mathrm{V}$ is spectral data and elemental analysis. The spectral data are in accordance with the expected structures. Elemental analysis showed that the percentage of the nitrogen, hydrogen and carbon was found experimentally is equivalent to the calculated values in all compounds. For starting material, ${ }^{1} \mathrm{H}-\mathrm{NMR}$ spectrum of compound 3 showed obviously peak of $\mathrm{NH}$ proton at $10.75 \mathrm{ppm}$ confirmed the condensation of 4-chlorobenzenesulfonylchloride and 4-aminoacetophenone. In addition, it showed the important peak of NH in IR spectrum at $3257 \mathrm{~cm}^{-1}$. Eight sulfonamide chalcones $(5 \mathrm{a}-5 \mathrm{~h})$ were prepared by the Claisen-Schmidt condensation reaction between $\mathrm{N}$-(4acetylphenyl)-4-chlorobenzenesulfonamide (3) and different benzaldehydes (4) according to the method given in Scheme 1. All the reactions proceeded smoothly and in good yields (50-78\%). Compound $5 \mathrm{c}$ was chosen as a representative for structure elucidation. $5 \mathrm{c}$ was confirmed by the appearance of $\mathrm{NH}$ proton at 10.75 . Other peaks are the trans proton at 7.75 and $7.68 \mathrm{ppm}$ which confirm the condensation of starting material (3) and benzaldehyde. For the equivalent aromatic protons of ring $\mathrm{A}$ (Scheme 1), the signals appeared at 8.09 and $7.63 \mathrm{ppm}$. Equivalent aromatic protons of ring B showed the doublet signals at 7.92 and $7.40 \mathrm{ppm}$, respectively. Two doublet of equivalent aromatic proton of ring $\mathrm{C}$ were observed at 7.78 and $7.03 \mathrm{ppm}$. The methoxy protons appeared at $3.87 \mathrm{ppm}$. The UV-Vis spectrum of $5 \mathrm{c}$ showed three peaks at 213, 300 and $364 \mathrm{~nm}$ which can be assigned to $\pi-\pi^{*}$ transitions. The IR data of $5 \mathrm{c}$ shows a strong band at $2924 \mathrm{~cm}^{-1}$ due to N-H stretching. The peak at $1650 \mathrm{~cm}^{-1}$ is due to $\mathrm{C}=\mathrm{O}$ stretching vibrations. A sharp band belonging to $\mathrm{C}=\mathrm{C}$ stretching was observed at $1558 \mathrm{~cm}^{-1}$. The asymmetric and symmetric peaks of $\mathrm{S}=\mathrm{O}$ appeared at 1162 and $1092 \mathrm{~cm}^{-1}$, respectively.

\section{DETERMINATION OF MUSHROOM TYROSINASE INHIBITION in vitro}

The eight synthesized compounds were screened for their antityrosinase activity together with molecular docking study which shows the affinity of the synthesized compounds with the enzyme. The $\mathrm{IC}_{50}$ values are presented in Figure 3. Our results show that compounds (5a-5h) exhibit moderate to good activity against tyrosinase enzyme with $\mathrm{IC}_{50}$ values ranging from 0.43 $3.44 \mathrm{mM}$. Among the analogues tested, compound $5 \mathrm{c}$ shows the most potent inhibitory activity $\left(\mathrm{IC}_{50}=\right.$ $0.43 \pm 0.07 \mathrm{mM}$ ). Similarly, the $\mathrm{IC}_{50}$ value of compounds $5 \mathrm{~b}, 5 \mathrm{f}, 5 \mathrm{~g}$, and $5 \mathrm{~h}$ are $0.80 \pm 0.06,0.75 \pm 0.03,0.59 \pm 0.07$, and $0.78 \pm 0.03 \mathrm{mM}$, respectively, which are close to the $\mathrm{IC}_{50}$ value of kojic acid. This may be due to the interaction between chloride atom of the compounds with tyrosinase enzyme. Compounds $5 \mathrm{a}, 5 \mathrm{~d}$, and $5 \mathrm{e}$ 
show lower activity than kojic acid with the $\mathrm{IC}_{50}$ values $3.44 \pm 0.33,4.41 \pm 0.11$ and $1.39 \pm 0.11 \mathrm{mM}$, respectively. However, they can act as immediate inhibitors because they interact with the enzyme by other mechanism (Figure 4). It is noted that tri-methoxy substitutions showed good effect to tyrosinase inhibitory. In summarize, the position of methoxy substitution on ring $\mathrm{C}$ (Scheme 1) affects the enzyme inhibition ability of the compounds. The increment in number of methoxy groups led to a slight decrease in inhibitory activities (compounds $5 \mathrm{~d}$, $5 \mathrm{e}, 5 \mathrm{f}, 5 \mathrm{~g}$, and $5 \mathrm{~h}$ ) indicating that the methoxy group on ring $\mathrm{C}$ might cause steric hindrance for the inhibitors approaching the active site. In addition, the connection of sulfonamide moiety to the structure of chalcone at paraposition of phenyl ring affects the inhibitory activity, which indicated that sulfonamide part has interaction with the active site of tyrosinase enzyme.

\section{MOLECULAR DOCKING RESULT}

Molecular docking was performed to study the interactions and selectivity of the compounds against mushroom tyrosinase enzyme (Figure 4). The binding energy of the docked synthetic ligands and tropolone is summarized in Table 1. Tropolone is often used as tyrosinase standard (Espín \& Wichers 1999) which displays potential tyrosinase inhibitor by competitive mechanism (Kahn \& Andrawis 1985). In addition, it has similar structure with kojic acid. From our docking results it was possible to recognize two different modes of binding in which a 'competition' and a 'not-competition'. Compounds 5c, $5 \mathrm{f}, 5 \mathrm{~g}$ and $5 \mathrm{~h}$, are docked at the same site of tropolone (Figure 4) which is in agreement with our hypothesis that the synthesized compounds might show the same mode of action as tropolone. Considering both; in vitro and in silico molecular docking results, among these eight synthesized compounds, $5 \mathrm{c}$, the compound with para-methoxy substituent, showed the best result and can be a potent inhibitor of tyrosinase enzyme with the binding energy being ca. $-10 \mathrm{kcal} / \mathrm{mol}$ (Table 1). The important interaction would be the hydrogen bond between the sulfonamide moiety of $5 \mathrm{c}$ with the amino moiety of Val 283 in active site of enzyme. In addition, the parallel-displaced conformation observed between the chlorobenzene ring of 5c with Phe264 at the active site has further strengthened the interaction between $5 \mathrm{c}$ with tyrosinase. These interactions would thus explain and correlate with our experimental $\mathrm{IC}_{50}$ values mentioned earlier. For compounds $5 \mathrm{f}, 5 \mathrm{~g}$, and $5 \mathrm{~h}$, the compounds containing tri-methoxy substituents, were docked at the tropolone binding site with the binding energy -8.17 , -8.44 , and $-8.49 \mathrm{kcal} / \mathrm{mol}$, respectively (Table 1 ).

TABLE 1. Free energy of binding for sulfonamide chalcone series with tyrosinase of $A$. bisporus

\begin{tabular}{cc}
\hline Ligand & Estimated free energy of binding $(\mathrm{FEB} ; \mathrm{kcal} / \mathrm{mol})$ \\
\hline $5 \mathrm{a}$ & -8.49 \\
$5 \mathrm{~b}$ & -7.48 \\
$5 \mathrm{c}$ & -9.99 \\
$5 \mathrm{~d}$ & -7.63 \\
$5 \mathrm{e}$ & -9.19 \\
$5 \mathrm{f}$ & -8.17 \\
$5 \mathrm{~g}$ & -8.44 \\
$5 \mathrm{~h}$ & -8.49 \\
Tropolone & -6.28 \\
\hline
\end{tabular}


The docking results agreed with the observed in vitro data, which showed that those compounds had lower tyrosinase inhibitory activity than $5 \mathrm{c}$. For that reason, the steric effect of the substituent group is probably the factor to explain the inhibition of tyrosinase activity. Moreover, compounds 5a, 5b, 5d, and 5e were docked at $-8.49,-7.48,-7.63$, and $-9.19 \mathrm{kcal} / \mathrm{mol}$, respectively. Even though they are not chelating agents, they could act as immediate inhibitors because they docked at different site with tropolone (Figure 4). It is also interesting to note that compound $5 \mathrm{~d}$ was one of the compounds with the least favourable binding free energy, which also correlate with the experimental $\mathrm{IC}_{50}$ values. The binding interactions of $5 \mathrm{f}, 5 \mathrm{~g}$, and $5 \mathrm{~h}$ could be similar with that of $5 \mathrm{c}$ (as in hydrogen bonding and ring stacking interaction) as these compounds docked at the same binding site with $5 \mathrm{c}$. For $5 \mathrm{c}, 5 \mathrm{f}, 5 \mathrm{~g}$, and $5 \mathrm{~h}$, their cholorobenzene ring of, were found position at tropolone binding site which was located at the inner active side of tyrosinase, thus further evidenced in stronger binding affinity with the rest of the test compounds. As for 5a, 5b, 5d, and 5e, they were docked at the entrance of the tyrosinase active site which could block the recruitment of the substrate of tyrosinase. Thus, this explain that these compounds might be able to act as immediate inhibitor as mentioned earlier.<smiles>O=C(/C=C/c1ccc(O)cc1)c1ccc(O)cc1O</smiles>

1<smiles>O=C(/C=C/c1ccc(O)c(O)c1)c1c(O)cc(O)cc1O</smiles>

3<smiles>COc1ccc(/C=C/C(=O)c2c(O)cc(OC)cc2OC)cc1</smiles>

2<smiles>COc1ccc(/C=C/C(=O)c2ccc(O)cc2O)c(OC)c1</smiles>

4

FIGURE 1. Some chalcone derivatives with tyrosinase inhibition effect<smiles>[R][R]1ccc(C(=O)/C=C/c2ccc([R])cc2)cc1</smiles>

Previous work<smiles>COc1ccc(/C=C/C(=O)c2ccc(NS(=O)(=O)c3ccc(Cl)cc3)cc2)cc1</smiles>

Designed compounds with possible binding site

FIGURE 2. The designed structure of sulfonamide chalcones with possible binding sites (encircled) 
<smiles>CC(=O)c1ccc(N)cc1</smiles>

1

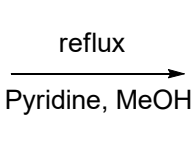

2<smiles>CC(=O)c1ccc(NS(=O)(=O)c2ccc(Cl)cc2)cc1</smiles>

3<smiles>COO[Si](C)(O)O[Na]</smiles><smiles>[R]c1ccc(/C=C/C(=O)c2ccc(NS(=O)(=O)c3ccc(Cl)cc3)cc2)cc1</smiles>
5a; $\mathrm{R}=2-\mathrm{OCH}_{3}$
5d; $\mathrm{R}=2,3-\mathrm{OCH}_{3}$
5f; $\mathrm{R}=2,4,5-\mathrm{OCH}_{3}$
5b; $\mathrm{R}=3-\mathrm{OCH}_{3}$
$\mathbf{5 e} ; \mathrm{R}=3,4-\mathrm{OCH}_{3}$
5g; $\mathrm{R}=2,4,6-\mathrm{OCH}_{3}$
5c; $\mathrm{R}=4-\mathrm{OCH}_{3}$
5h; $\mathrm{R}=3,4,5-\mathrm{OCH}_{3}$

SCHEME 1. Synthesis of sulfonamide chalcones (5a-5h)

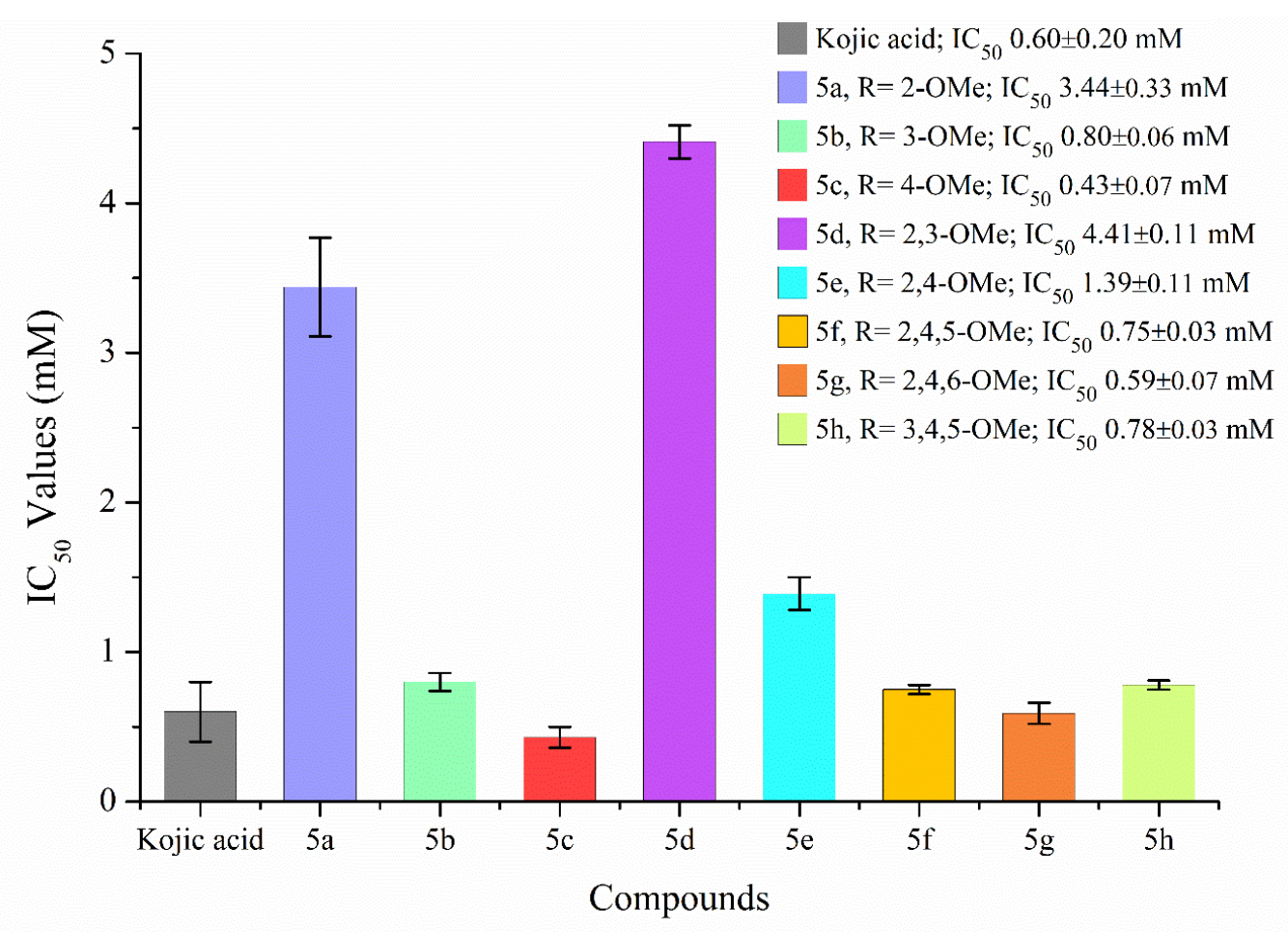

FIGURE 3. Tyrosinase inhibition of sulfonamide chalcones (5a-5h) and kojic acid 

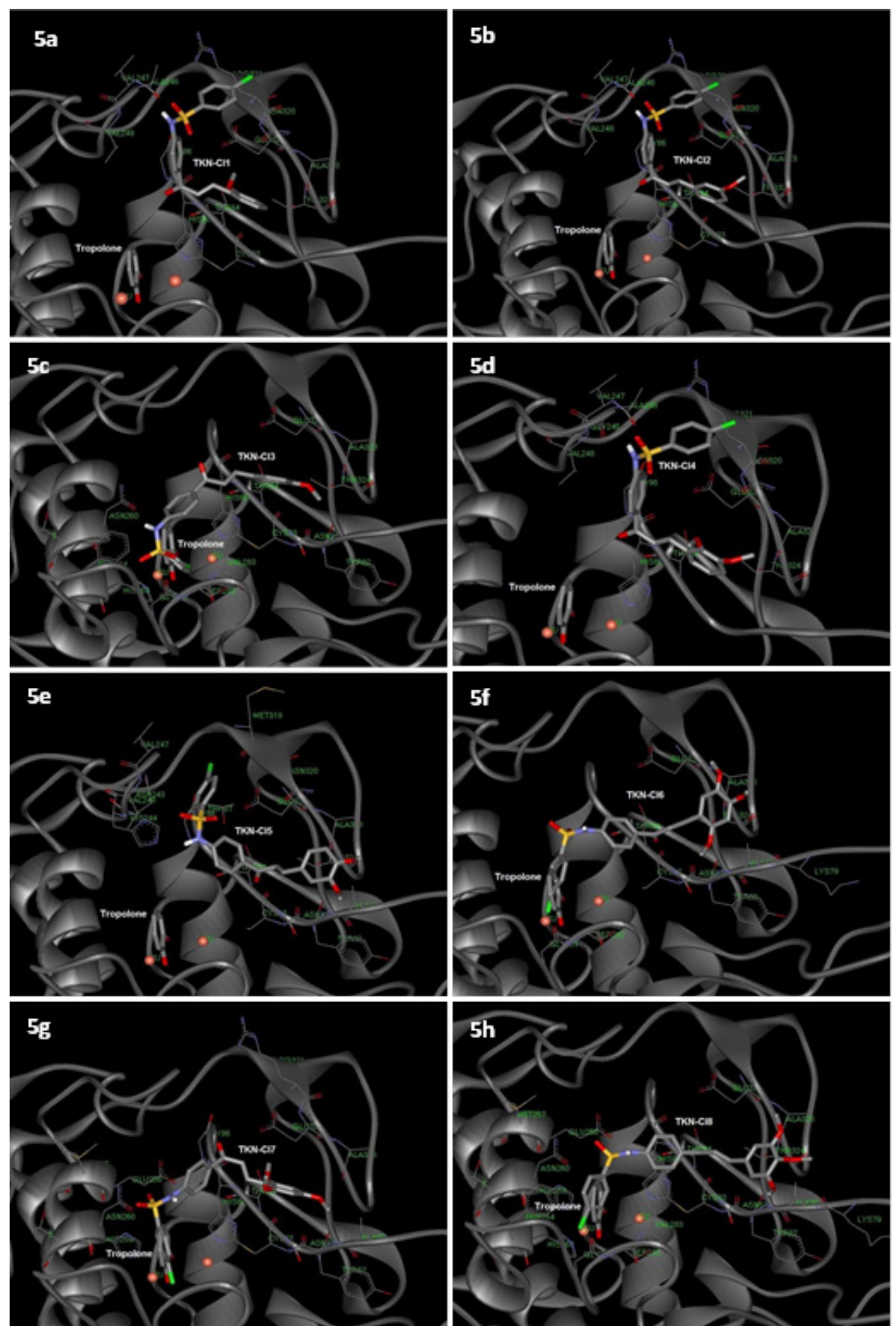

FIGURE 4. The superimposition of docked conformation for tropolone (stick representation) compared with sulfonamide chalcone series (5a-5h; stick representation) in the binding pocket (line representation) of $A$. bisporus tyrosinase (grey ribbon representation). Copper atoms are in orange sphere representation

\section{CONCLUSION}

To conclude, we successfully designed and synthesized sulfonamide compounds which possess tyrosinase inhibitory activity with various binding sites. Eight sulfonamide chalcones were synthesized and characterized by ${ }^{1} \mathrm{H}-\mathrm{NMR}$, IR and UV-Vis spectroscopy. 
Tyrosinase inhibitory activity were carried out and compared with the standard kojic acid. It was found that compound $5 \mathrm{c}$ exhibits significant tyrosinase inhibitory with L-DOPA as substrate with the $\mathrm{IC}_{50}$ of $0.43 \pm 0.07$ $\mathrm{mM}$, which is better than that of the standard kojic acid $(0.60 \pm 0.20 \mathrm{mM})$. From the docking results, sulfonamide chalcones $5 \mathrm{c}, 5 \mathrm{f}, 5 \mathrm{~g}$, and $5 \mathrm{~h}$ show the same inhibition mechanism mode as tropolone in which through the metal chelating effects and it can bind with the receptor with high binding affinity. Our results imply that sulfonamide moiety is important for the increasing of the tyrosinase inhibition activity of chalcones. Moreover, the increment in the number of methoxy might cause stereo hindrance for the inhibitors approaching the active site of the enzyme resulting in the decrease of inhibitory activities. These compounds may be good candidates for rational drug designing for the multi-functional tyrosinase inhibitor.

\section{ACKNOWLEDGEMENTS}

SC thanks Division of Physical Science, Faculty of Science for research facilities. Financial support by Faculty of Science, Prince of Songkla University is gratefully acknowledged.

\section{REFERENCES}

Akhtar, M.N., Sakeh, N.M., Zareen, S., Gul, S., Lo, K.M., Ul-Haq, Z., Shah, S.A.A. \& Ahmad, S. 2015. Design and synthesis of chalcone derivatives as potent tyrosinase inhibitors and their structural activity relationship. Journal of Molecular Structure 1085: 97-103.

Ali, T.E. \& Abdel-Rahman, R.M. 2014. Synthesis and antioxidant activities of some novel fluorinated spiro [oxindole-thiazolidine] fused with sulfur and phosphorus heterocycles. Journal of Sulfur Chemistry 35(4): 399-411.

Ashraf, A., Ejaz, S.A., Rahman, S.U., Siddiqui, W.A., Arshad, M.N., Lecka, J., Sévigny, J., Zayed, M.E.M., Asiri, A.M., Iqbal, J. \& Hartinger, C.G. 2018. Hybrid compounds from chalcone and 1,2-benzothiazine pharmacophores as selective inhibitors of alkaline phosphatase isozymes. European Journal of Medicinal Chemistry 159: 282-291.

Battin, E.E. \& Brumaghim, J.L. 2009. Antioxidant activity of sulfur and selenium: A review of reactive oxygen species scavenging, glutathione peroxidase, and metal-binding antioxidant mechanisms. Cell Biochemistry and Biophysics 55(1): 1-23.

Bharatham, K., Bharatham, N., Park, K.H. \& Lee, K.W. 2008. Binding mode analyses and pharmacophore model development for sulfonamide chalcone derivatives, a new class of $\alpha$-glucosidase inhibitors. Journal of Molecular Graphics and Modelling 26(8): 1202-1212.

Bonakdar, A.P.S., Vafaei, F., Farokhpour, M., Esfahani, M.H.N. \& Massah, A.R. 2017. Synthesis and anticancer activity assay of novel chalcone-sulfonamide derivatives. Iranian Journal of Pharmaceutical Research 16(2): 565.

Cai, P., Xiong, Y., Yao, Y., Chen, W. \& Dong, X. 2019. Synthesis, screening and biological activity of potent thiosemicarbazone compounds as a tyrosinase inhibitor. New Journal of Chemistry 43(35): 14102-14111.

Carcelli, M., Rogolino, D., Bartoli, J., Pala, N., Compari, C., Ronda, N., Bacciottini, F., Incerti, M. \& Fisicaro, E. 2020. Hydroxyphenyl thiosemicarbazones as inhibitors of mushroom tyrosinase and antibrowning agents. Food Chemistry 303: 125310.

Chang, T.S. 2009. An updated review of tyrosinase inhibitors. International Journal of Molecular Sciences 10(6): 24402475.

Domínguez, J.N., León, C., Rodrigues, J., de Domínguez, N.G., Gut, J. \& Rosenthal, P.J. 2005. Synthesis and antimalarial activity of sulfonamide chalcone derivatives. Il Farmaco 60(4): 307-311.

Espín, J.C. \& Wichers, H.J. 1999. Slow-binding inhibition of mushroom (Agaricus bisporus) tyrosinase isoforms by tropolone. Journal of Agricultural and Food Chemistry 47(7): 2638-2644.

Gantla, C.R., Suresh, Y., Harikrishana, S. \& Shrivastava, S.P. 2009. Synthesis and antibacterial activity of some substituted isoxazolines and isothiazolines. Oriental Journal of Chemistry 25(1): 153-157.

Ismaya, W.T., Rozeboom, H.J., Weijn, A., Mes, J.J., Fusetti, F., Wichers, H.J. \& Dijkstra, B.W. 2011. Crystal structure of Agaricus bisporus mushroom tyrosinase: Identity of the tetramer subunits and interaction with tropolone. Biochemistry 50(24): 5477-5486.

Javle, M. \& Curtin, N.J. 2011. The potential for poly (ADP-ribose) polymerase inhibitors in cancer therapy. Therapeutic Advances in Medical Oncology 3(6): 257-267.

Kahn, V. \& Andrawis, A. 1985. Inhibition of mushroom tyrosinase by tropolone. Phytochemistry 24(5): 905-908.

Kang, J.E., Cho, J.K., Curtis-Long, M.J., Ryu, H.W., Kim, J.H., Kim, H.J., Yuk, H.J., Kim, D.W. \& Park, K.H. 2013. Inhibitory evaluation of sulfonamide chalcones on $\beta$-secretase and acylcholinesterase. Molecules 18(1): 140153.

Khatib, S., Nerya, O., Musa, R., Shmuel, M., Tamir, S. \& Vaya, J. 2005. Chalcones as potent tyrosinase inhibitors: The importance of a 2, 4-substituted resorcinol moiety. Bioorganic \& Medicinal Chemistry 13(2): 433-441.

Kim, J.H., Jang, H.J., Cho, W.Y., Yeon, S.J. \& Lee, C.H. 2020. In vitro antioxidant actions of sulfur-containing amino acids. Arabian Journal of Chemistry 13(1): 1678-1684.

Lee, B., Moon, K.M., Kim, S.J., Kim, S.H., Kim, D.H., An, H.J., Jeong, J.W., Kim, Y.R., Son, S., Kim, M.J. \& Chung, K.W. 2016. (Z)-5-(2, 4-dihydroxybenzylidene) thiazolidine-2, 4-dione prevents UVB-induced melanogenesis and wrinkle formation through suppressing oxidative stress in HRM-2 hairless mice. Oxidative Medicine and Cellular Longevity 2016: 2761463. 
Liu, J., Chen, C., Wu, F. \& Zhao, L. 2013. Microwave-assisted synthesis and tyrosinase inhibitory activity of chalcone derivatives. Chemical Biology \& Drug Design 82(1): 39-47.

Liu, J., Wu, F., Chen, L., Hu, J., Zhao, L., Chen, C. \& Peng, L. 2011. Evaluation of dihydropyrimidin- $(2 \mathrm{H})$-one analogues and rhodanine derivatives as tyrosinase inhibitors. Bioorganic \& Medicinal Chemistry Letters 21(8): 2376-2379.

Loizzo, M.R., Tundis, R. \& Menichini, F. 2012. Natural and synthetic tyrosinase inhibitors as antibrowning agents: An update. Comprehensive Reviews in Food Science and Food Safety 11(4): 378-398.

Morris, G.M., Goodsell, D.S., Halliday, R.S., Huey, R., Hart, W.E., Belew, R.K. \& Olson, A.J. 1998. Automated docking using a Lamarckian genetic algorithm and an empirical binding free energy function. Journal of Computational Chemistry 19(14): 1639-1662.

Nerya, O., Musa, R., Khatib, S., Tamir, S. \& Vaya, J. 2004. Chalcones as potent tyrosinase inhibitors: The effect of hydroxyl positions and numbers. Phytochemistry 65(10): 1389-1395.

Nithitanakool, S., Pithayanukul, P., Bavovada, R. \& Saparpakorn, P. 2009. Molecular docking studies and anti-tyrosinase activity of Thai mango seed kernel extract. Molecules 14(1): 257-265.

Niu, C., Yin, L., Nie, L.F., Dou, J., Zhao, J.Y., Li, G. \& Aisa, H.A. 2016. Synthesis and bioactivity of novel isoxazole chalcone derivatives on tyrosinase and melanin synthesis in murine B16 cells for the treatment of vitiligo. Bioorganic \& Medicinal Chemistry 24(21): 5440-5448.

Panzella, L. \& Napolitano, A. 2019. Natural and bioinspired phenolic compounds as tyrosinase inhibitors for the treatment of skin hyperpigmentation: Recent advances. Cosmetics 6(4): 57.

Park, K.H., Kim, J.H., Seo, W.D., Ryu, Y.B., Ryu, H.W., Lee, W.S., Gal, S.W. \& Gyeongsang National University Industry-Academic Cooperation Fdn. 2010. Chalcone derivatives, pharmaceutically acceptable salt, method for preparation and uses thereof. U.S. Patent 7,851,654.

Parvez, S., Kang, M., Chung, H.S. \& Bae, H. 2007. Naturally occurring tyrosinase inhibitors: Mechanism and applications in skin health, cosmetics and agriculture industries. Phytotherapy Research: An International Journal Devoted to Pharmacological and Toxicological Evaluation of Natural Product Derivatives 21(9): 805-816.

Radhakrishnan, S., Shimmon, R., Conn, C. \& Baker, A. 2015a. Inhibitory kinetics of novel 2,3-dihydro-1H-inden-1one chalcone-like derivatives on mushroom tyrosinase. Bioorganic \& Medicinal Chemistry Letters 25(23): 54955499.

Radhakrishnan, S., Shimmon, R., Conn, C. \& Baker, A. 2015b. Design, synthesis and biological evaluation of hydroxy substituted amino chalcone compounds for antityrosinase activity in B16 cells. Bioorganic Chemistry 62: 117-123.
Radhakrishnan, S., Shimmon, R., Conn, C. \& Baker, A. 2015c. Integrated kinetic studies and computational analysis on naphthyl chalcones as mushroom tyrosinase inhibitors. Bioorganic \& Medicinal Chemistry Letters 25(19): 40854091.

Ranjbar, S., Akbari, A., Edraki, N., Khoshneviszadeh, M., Hemmatian, H., Firuzi, O. \& Khoshneviszadeh, M. 2018. 6-Methoxy-3,4-dihydronaphthalenone chalcone-like derivatives as potent tyrosinase inhibitors and radical scavengers. Letters in Drug Design \& Discovery 15(11): 1170-1179.

Rescigno, A., Bruyneel, F., Padiglia, A., Sollai, F., Salis, A., Marchand-Brynaert, J. \& Sanjust, E. 2011. Structure - Activity relationships of various amino-hydroxy-benzenesulfonic acids and sulfonamides as tyrosinase substrates. Biochimica et Biophysica Acta 1810(8): 799-807.

Seo, S.Y., Sharma, V.K. \& Sharma, N. 2003. Mushroom tyrosinase: Recent prospects. Journal of Agricultural and Food Chemistry 51(10): 2837-2853.

Seo, W.D., Ryu, Y.B., Curtis-Long, M.J., Lee, C.W., Ryu, H.W., Jang, K.C. \& Park, K.H. 2010. Evaluation of anti-pigmentary effect of synthetic sulfonylamino chalcone. European Journal of Medicinal Chemistry 45(5): 2010-2017.

Suwunwong, T., Kobkeatthawin, T., Chanawanno, K., Saewan, N., Wisitsak, P. \& Chantrapromma, S. 2012. Tyrosinase inhibitory activity of pyrazole derivatives. Advanced Materials Research 506: 194-197.

Yamada, M., Nakamura, K., Watabe, T., Ohno, O., Kawagoshi, M., Maru, N., Uotsu, N., Chiba, T., Yamaguchi, K. \& Uemura, D. 2011. Melanin biosynthesis inhibitors from tarragon Artemisia dracunculus. Bioscience, Biotechnology, and Biochemistry 75(8): 1628-1630.

Yi, L. \& Su, Q. 2013. Molecular mechanisms for the anti-cancer effects of diallyl disulfide. Food and Chemical Toxicology 57: 362-370.

Thawanrat Kobkeatthawin \& Suchada Chantrapromma* Division of Physical Science

Faculty of Science

Prince of Songkla University

Songkhla 90110

Thailand

Thitipone Suwunwong

School of Science

Mae Fah Luang University

Chiang Rai 57100

Thailand

Lydia Rhyman \& Ponnadurai Ramasami

Computational Chemistry Group

Department of Chemistry, Faculty of Science

University of Mauritius

Réduit 80837

Mauritius 
Lydia Rhyman \& Ponnadurai Ramasami

Centre for Natural Product Research

Department of Chemical Sciences

University of Johannesburg

Doornfontein Campus, Johannesburg 2028

South Africa

Yee Siew Choong

Computational Institute for Research in Molecular Medicine (INFORMM)

Universiti Sains Malaysia

USM 11800

Malaysia
*Corresponding author; email: suchada.c@psu.ac.th

Received: 17 May 2020

Accepted: 13 January 2021 